\title{
Maximizing Agricultural Residues: Nutritional Properties of Straw Mushroom on Maize Husk, Waste Cotton and Plantain Leaves
}

\author{
Olutayo M. Adedokun*, A. H. Akuma \\ Department of Crop and Soil Science, Faculty of Agriculture, University of Port-Harcourt, Port-Harcourt, Nigeria. \\ Email: *Olutayo.adedokun@gmail.com
}

Received October $2^{\text {nd }}, 2013$; revised November $4^{\text {th }}, 2013$; accepted November $26^{\text {th }}, 2013$

Copyright (c) 2013 Olutayo M. Adedokun, A. H. Akuma. This is an open access article distributed under the Creative Commons Attribution License, which permits unrestricted use, distribution, and reproduction in any medium, provided the original work is properly cited. In accordance of the Creative Commons Attribution License all Copyrights @ 2013 are reserved for SCIRP and the owner of the intellectual property Olutayo M. Adedokun, A. H. Akuma. All Copyright (C) 2013 are guarded by law and by SCIRP as a guardian.

\begin{abstract}
The straw mushroom, Volvariella volvacea (Bulliard ex Fries) Singer, (V. volvacea), a tropical and sub-tropical mushroom is an invaluable vegetable. Nutritional properties of straw mushrooms grown on plantain leaves, maize husk and waste cotton were investigated. Aim: The aim of this study was to recommend these agro-wastes for mushroom production by farmers instead of relying solely on seasonal wild hunting, and to promote consumption of the mushroom. Method: Ten percent (10\%) of the mushrooms spawn was used to inoculate $500 \mathrm{~g}$ of each substrate in plastic baskets. Mushrooms were harvested after twenty days of incubation followed by proximate analysis of the fruiting bodies. Results: Results indicated that the fruiting bodies harvested from the substrates varied significantly $(\mathrm{P}<0.05)$ in carbohydrate, protein, ash and fiber percentage, with maize having the highest value. However, no significant difference was observed in moisture and lipid content. Mushrooms grown on maize substrate showed better nutritional properties compared with other substrates. Conclusion: These agro wastes are recommended for production of $V$. volvacea.
\end{abstract}

Keywords: Straw Mushroom; Plantain Leaves; Maize Husk; Nutritional Content; Wild Hunting; Year-Round Production

\section{Introduction}

Advocacy on consumption and cultivation of mushroom is increasing by the day. The International Society for Mushroom Science is championing the global campaign and has launched a health initiative in this regard since 2008 [1]. The potentials of mushrooms to address current food crisis problems in Africa, developing countries as well as future problems resulting from population explosion were reported by Mshandete and Cuff [2]. For mushrooms to be adequately promoted for cultivation and consumption, there is a need for basic knowledge of their medicinal and nutritional composition. This knowledge will make campaign for cultivation and consumption easier and probably reduce malnutrition and poverty especially in third world counties. It is also essential to equip the populace with available and abundant sub-

${ }^{*}$ Corresponding author. strates for cultivation.

Ahlawat and Tewari [3] and Hamlyn [4] reported that $V$. volvacea was cultivated on paddy straw before 1970 . In 1971, with the introduction of cotton waste as substrate which gave a high yield, it completely replaced paddy straw in 1973 in Hong Kong. Reyes et al. [5] and Onuoha et al. [6] reported that V. volvacea could be grown on agricultural wastes while Phillippoussis et al. [7] reported that the mushroom performed better on cotton waste. This is a good substitute where cotton waste is in abundance but what happens where it is not easily available? Nigeria is the $10^{\text {th }}$ largest producer of maize in the world and the largest maize producer in Africa [8] with 9180270.00 tons production in 2011 [9]. The country is the $4^{\text {th }}$ largest producer of plantain in Sub Saharan Africa and the $2^{\text {nd }}$ in West Africa [10] with production of 2700000.00 tons in 2011 [9]. However, cotton production was only 283160.00 tons in 2011 [9]. 
A growth trial and nutritional analysis of $V$. volvacea was made on plantain leaves and maize husk, which are abundant agricultural wastes in Nigeria. This was compared with results from cotton waste in order to assess the substrates and advise farmers especially women who do not have easy access to cotton waste for cultivation of $V$. volvacea. Although Mshandete and Cuff [2] reported that both in Africa and globally, mushrooms collected during the rains are culturally accepted and regarded as important nutritious food, while seasonal production is important, it is imperative to domesticate mushrooms making them available all year-round and to investigate their assessment as food. The objective of this study was to investigate the effect of growth substrates on nutritional composition of cultivated $V$. volvacea.

\section{Materials and Methods}

\subsection{Study Area}

The study was conducted in the Faculty of agriculture demonstration farm, mushroom unit, University of Port Harcourt, River State, Nigeria.

\subsection{Experimental Design and Replication}

The experimental design was a complete randomized design (CRD) with three treatments replicated three times.

\subsection{Source of Materials}

\subsubsection{Growth Substrates}

Three agro-waste materials were used as substrates in this study. These include plantain (Musa paradisiaca, AAB Group) leaves, cotton (Gossypium sapiens) wastes and maize (Zea maize) husk. Plantain leaves and maize husks were collected from the University of Port Harcourt teaching and research farm, while cotton waste was obtained from Atlantic textile mills in Lagos, Nigeria.

\subsubsection{Spawn}

Already prepared spawn of $V$. volvacea was acquired from Bezaleel Mushrooms in Port Harcourt.

\subsection{Substrate Preparation}

The plantain leaves and maize husks were dried and chopped manually to 3 centimeters. $200 \mathrm{~g}$ of each substrate was weighed soaked in 2 liters of water and mixed with $20 \%$ of wheat bran and $5 \%$ of calcium carbonate. After mixing, the substrates were sterilized using an autoclave at $121^{\circ} \mathrm{C}$ for 15 minutes. The substrate was cooled to about $50^{\circ} \mathrm{C}$, poured into a plastic basket and inoculated with $10 \%$ of spawn. Growing basket was covered with white polythene bag overlaid with black and incubated for 20 days at room temperature $28 \pm 2^{\circ} \mathrm{C}$.

\subsection{Data Collection}

The following growth and yield parameters were recorded.

\subsubsection{Number of Fruiting Bodies}

This was done by counting the numbers of fruit bodies on each substrate.

\subsubsection{Weight of the Fruit Bodies}

An electronic kitchen scale SF-400 capacity (5000 g × 1 $\mathrm{g} / 20002 \times 0.102)$ was used to determine the average weight of the fruit bodies.

\subsubsection{Nutritional Content}

This was analyzed in the laboratory using proximate analysis.

\subsubsection{Fruiting and Harvesting}

The substrates were watered every morning. Within 20 days white pin heads appeared on the substrates. After 10 days, the pins developed into mature fruiting bodies of brown color and were harvested. The fruiting bodies of $V$. volvacea mushrooms were harvested on the different substrates and proximate analysis was carried out.

\subsubsection{Determination of Nutritional Contents}

The following parameters were analyzed using the standard AOAC procedure - carbohydrate, lipid, protein, ash, moisture and fiber content [11].

All data collected was subjected to analysis of variance (ANOVA).

\section{Results}

Volvariella volvacea grew on all the substrates. There was no significant difference between the numbers and weight of fruit recorded on the different substrate (Table 1).

Table 1. Number and weight of fruiting bodies on different substrates.

\begin{tabular}{ccc}
\hline Treatment & Number of fruiting bodies & Weight of fruiting bodies \\
\hline Cotton waste & 5.00 & 18.67 \\
Maize husk & 5.33 & 24.67 \\
Plantain leave & 4.33 & 15.33 \\
Mean & 4.89 & 19.89 \\
LSD $(0.05)$ & NS & NS \\
\hline
\end{tabular}

There was no significant difference $(\mathrm{NS})$ at $(\mathrm{P}<0.05)$ between the number and weight of fruiting bodies. 
Figure 1 shows the fruiting body on maize. The result of the nutritional analysis is represented in Table 2. The fruiting bodies harvested from the test substrates varied significantly in carbohydrate, protein, ash and fiber percentage at $(\mathrm{P}<0.05)$, while there was no significant difference at $(\mathrm{P}<0.05)$ in moisture and lipid contents among the three substrates. Higher carbohydrate content was observed in the fruiting bodies harvested from maize husks; however the carbohydrate level was not significantly different from the mushrooms grown on plantain leaves. Mushrooms grown on cotton waste gave the lowest carbohydrate content.

Furthermore the highest and lowest total ash contents of $V$. volvacea were recorded from maize husks and cotton waste respectively, as indicated in (Table 2); but there was no significant difference between ash content obtained from maize husks and plantain leaves.

The moisture contents on (Table 2) showed that there was no significant difference $(\mathrm{P}<0.05)$ among the three

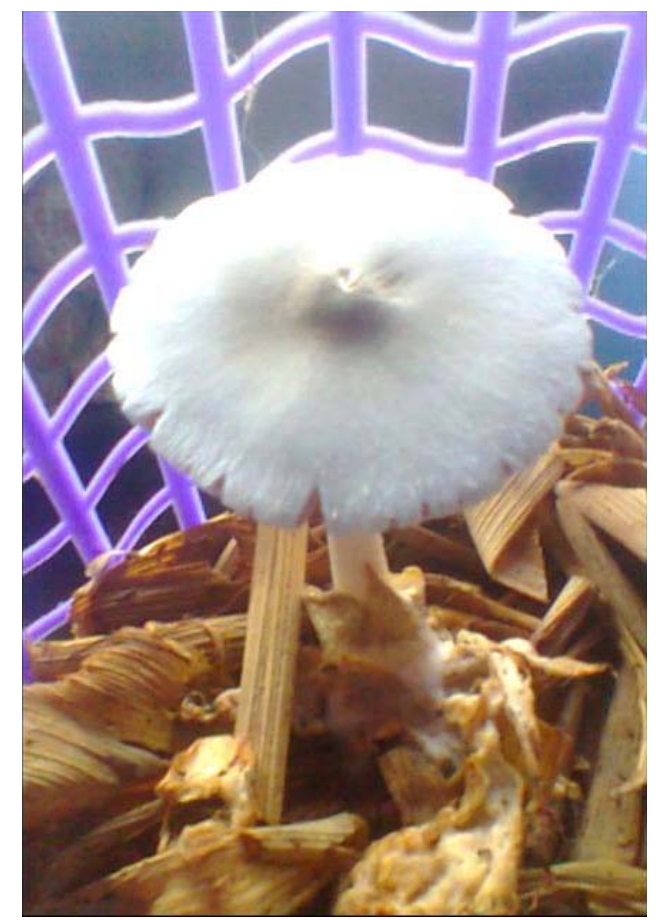

Figure 1. Fruiting body of $V$. volvacea on maize husks.

Table 2. Proximate analysis of $V$. volvacea on the different substrates.

\begin{tabular}{ccccccc}
\hline Treatment & Carbohydrate & Lip & Pro & Ash & Moisture & Fiber \\
\hline Cotton waste & 1.027 & 0.103 & 1.419 & 0.653 & 96.280 & 2.839 \\
Maize husk & 1.393 & 0.135 & 2.301 & 1.179 & 94.500 & 3.656 \\
$\begin{array}{c}\text { Plantain } \\
\text { leave }\end{array}$ & 1.377 & 0.109 & 1.013 & 0.950 & 95.666 & 2.777 \\
Mean & 1.266 & 0.115 & 1.578 & 0.927 & 95.482 & 3.0907 \\
LSD (0.05) & 0.110 & Ns & 0.440 & 0.243 & Ns & 0.269 \\
\hline
\end{tabular}

agricultural wastes used to cultivate $V$. volvacea. The highest fiber content obtained was on maize husk, which was significantly different from plantain leaves and cotton wastes. There was no significant difference $(\mathrm{P}<0.05)$ between the fiber content of plantain leaves and cotton wastes.

\section{Discussion}

The three substrates, cotton wastes, plantain leaves and maize husks supported the growth of $V$. volvacea, indicating efficient bio-conversion of these agricultural wastes. The ability of $V$. volvacea to degrade these agricultural wastes makes it a useful tool in waste management as well as in nutrition. Onuoha et al., [6] reported that Volvariella volvacea could be grown on agricultural wastes. Akinyele and Akinyosoye [12]; Peng [13] reported the same view furthermore, observed that these wastes are produced in large volumes during agricultural crop production every year causing significant environmental problems in many countries. Only a very small part of these agro-wastes have been properly converted into useful or high -value products. In a similar report on oyster mushroom, Akinyele et al. [14] reported conversion of agrowastes to useful biological products by oyster mushrooms while Ghosh et al. [15] observed that various species and strains of this edible mushroom are able to utilize woody materials and non-woody materials efficiently by degrading their ligno-cellulosic ingredients. Since maize husks and plantain leaves (which are wastes after harvesting maize seeds and plantain fingers) are so abundant, farmers should be encouraged to employ them as substrates for mushroom production.

The significant difference observed for carbohydrate, protein, ash and fiber content may possibly be due to the different composition of the substrates and the rate at which the mushrooms use secreted enzymes to convert the lignocellulose compound to useful product with the aid of enzyme secreted. Diego et al. [16] reported that substrates are both a physical support and a source of nutrients for the mushrooms to complete their life cycle from vegetative to reproductive phases.

The lipid contents obtained from the substrates showed no significant difference among the three substrates used. This observation is similar to the work of Haq et al. [17] who reported similar lipid content for $V$. volvacea. The low lipid content probably contributed to mushrooms being referred to as 'healthy food'. The observation made on ash and fiber is similar to the reports of Wani et al. [18] and Haq et al. [17] respectfully.

\section{Conclusion}

Mushroom cultivation holds three main advantages: It is 
an effective means to extract bio-resource left in agricultural waste materials simultaneously, a sound environmental protection strategy as well as an economic development tool. The present study showed that $V$. volvacea can be successfully cultivated on maize husks, plantain leaves and cotton wastes. These three substrates can be recommended for the commercial cultivation of $\mathrm{V}$. volvacea. Although waste cotton is not readily available and may be expensive for average farmers, farmers may use maize husks and plantain leaves to cultivate $V$. volvacea (because of its high nutritional and medicinal values) after harvesting their agricultural produce. In this way, there will be a year-round supply of $V$. volvacea rather than seasonal wild hunting.

\section{Acknowledgements}

The Authors appreciate Dr. Helga Recke (African Women in Agricultural Research and Development) and Dr. Sandra Williams (Mushroom in Ghana Project) for reviewing the manuscripts prior to submission.

\section{REFERENCES}

[1] Mushroom and Health Global Initiative Bulletin, 2008. http://www.xenoncorp.com/Images/MHGIBulletin_Feb0 8.pdf

[2] A. M. Mshandete and J. Cuff, "Proximate and Nutrient Composition of Three Types of Indigenous Edible Wild Mushrooms Grown in Tanzania and Their Utilization Prospects," Journal of Food, Agriculture, Nutrition and Development, Vol. 7, No. 6, 2007, pp. 1684-5374. http://www.bioline.org.br/request?nd07054

[3] O. P. Ahlawat and R. P. Tewari, "Cultivation Technology of Paddy Straw Mushroom (Volvariella volvacea),” Technical Bulletin, National Research Center for Mushroom (Indian Council of Agriculture), 2007, pp. 1-44.

[4] P. F. Hamlyn, "Cultivation of Edible Mushrooms on Cotton Waste,” The Mycologist, Vol. 3, No. 4, 1989, pp. 171173. http://dx.doi.org/10.1016/S0269-915X(89)80111-9

[5] R. G. Reyes, E. A. Abella, F. Eguchu, T. Lijima, M. Higaki and T. H. Quimio, "Growing Paddy Straw Mushrooms," Mushroom Growers' Handbook 1, 2004, pp. 248-255.

[6] C. I. Onuoha, G. Oyibo and J. Ebibila, "Cultivation of Straw Mushroom (Volvariella volvacea) Using Some Agro-Waste Material,” Journal of American Science, Vol. 5, No. 5, 2009, pp. 135-138.

[7] A. Philippoussis, G. Zervakis and P. Diamantopoulour, "Bioconversion of Agriculture Wastes through the Cultivation of the Edible Mushrooms," World Journal of Microbiology and Biotechnology, Vol. 17, No. 2, 2001, pp.
191-200. http://dx.doi.org/10.1023/A:1016685530312

[8] P. Cadoni and A. Angelucci, "Analysis of Incentives and Disincentives for Maize in Nigeria,” Technical Notes Series, MAFAP, FAO, Rome, 2013.

http://www.fao.org/fileadmin/templates/mafap/documents /technical_notes/NIGERIA/NIGERIA_Technical_Note_ MAIZE_EN_Jul2013.pdf

[9] FAO, “FAO Statistics Division,” 2013. http://faostat3.fao.org/faostatgateway/go/to/download/Q/ $\mathrm{QC} / \mathrm{E}$

[10] IITA, "IITA Bulletin, Research to Nourish Africa-Banana and Plantain,” International Institute of Tropical Agriculture, 2013. http://www.iita.org/banana-and-plaintain.

[11] Association of Official Analytical Chemistry (AOAC), "Official method of Analysis," 17th Edition, Association of Official Chemists, Maryland.

[12] B. J. Akinyele and F. A. Akinyosoye, "Effect of Volvariella volvacea Cultivation on the Chemical Composition of Agrowastes," African Journal of Biotechnology, Vol. 4, No. 9, 2005, pp. 979-983.

[13] J. T. Peng, "Agro-Waste for Cultivation of Edible Mushrooms in Taiwan”, Food and Fertilizer Technology Center Publication Database, 2010, pp. 1-5. http://www.agnet.org/library.php?func=view\&id=201107 25155730\&type_id $=4$

[14] B. J. Akinyele, O. O. Olaniyi and D. J. Arostupin, "Bioconversion of Selected Agricultural Wastes and Enzymes by Volvariella volvacea: An Edible Mushroom," Research Journal of Microbiology, Vol. 6, No. 1, 2011, pp. 63-73.

[15] M. Ghosh, R. Mukherjee and B. Nandi, "Production of Extracellular Enzymes by Two Pleurotus Species Using Banana Pseudostem Biomass,” Acta Biotechnologica, Vol. 18, No. 3, 1998, pp. 243-254. http://dx.doi.org/10.1002/abio.370180309

[16] C. Z. Diego, S. Jean-Michel and A. Pardo-Giménez, "Soybean the Main Nitrogen Source in Cultivation Substrates of Edible and Medicinal Mushrooms," Soybean and Nutrition, 2011.

http://www.intechopen.com/books/soybeanandnutrition/so ybean-the-main-nitrogen-source-in-cultivation-substrates-o f-edible-and-medicinal-mushrooms

[17] I. U. Haq, M. A. Khan, S. A. Khan and M. Ahmad, "Biochemical Analysis of Fruiting Bodies of Volvariella volvacea Strain VvPk, Grown on Six Different Substrates” Soil Science Society of Pakistan, Vol. 30, No. 2, 2011, pp. 146-150.

[18] B. A. Wani, R. H. Bodha and A. H. Wani, "Nutritional and Medicinal importance of mushrooms," Academic Journals of Medicinal Plants Research, Vol. 4, No. 24, 2010, pp. 2598-2604. 